УДК 336.7

DOI: https://doi.org/10.54929/pmt-issue1-2021-02

\title{
ОСОБЛИВОСТІ КРЕДИТНОЇ ТА ІНВЕСТИЦІЙНОЇ ПОЛІТИКИ МІЖНАРОДНИХ ФІНАНСОВИХ ОРГАНІЗАЦІЙ
}

\author{
FEATURES OF CREDIT AND INVESTMENT POLICY \\ OF INTERNATIONAL FINANCIAL ORGANIZATIONS
}

Островська Н. С.

д.е.н., доцент, доцент кафедри публічних, корпоративних фрінансів та фінансового посередництва, Чернівецький національний університет імені Юрія Федьковича, Чернівці ORCID ID: 0000-0002-7259-7403

Абделязіз Д. М.
здобувачка вищої освіти 6 курсу
спеціальності «Фінанси, банківська справа та страхування»,
Чернівецький національний університет імені Юрія Федьковича, Чернівці
Natalia Ostrovska
Doctor of Economics, Associate Professor,
Associate Professor of the Department of Public,
Corporate finance and financial intermediation,
Yuriy Fedkovych Chernivtsi National University, Chernivtsi
Diana Abdelaziz
6th year graduate

У статті досліджено особливості кредитної та інвестиційної політики міжнародних фрінансових організацій. Визначено, що на сучасному стані активізації процесів інтеграції та глобалізації життя міжнародного співтовариства поступово зростає вплив наднаціональних організацій на регулювання міжнародних, і зокрема, міждержавних відносин. Активізація зовнішньополітичної діяльності України передбачає ї̈ участь в таких міждержавних об'єднаннях. Досліджено, що інституційна будова світової фрінансової системи в умовах кризи була вимушена змінюватися. Зміни, що відбуваються носять не лише інституційний характер, але і функціональний та правовий - змінюються функції міжнародних фрінансових організацій, приймаються та затверджуються нові нормативи. Обгрунтовано, що суть кредитної та інвестиційної діяльності міжнародних фінансових організації полягає в сприянні розвитку підприємницької діяльності країн - позичальниць, залучення коштів для фінансування дефіциту державного бюджету та платіжного балансу, проведення структурних перебудов в економіці, реалізації окремих цільових соціально - економічних програм та забезпечення інших напрямів розвитку. Ключові слова: кредит, кредитування, кредитна політика, інвестиції, фрінансові організації.

В статье исследованы особенности кредитной и инвестиционной политики международных фринансовых организаций. Определено, что на современном состоянии активизации процессов интеграции и глобализации жизни международного сообщества постепенно растет влияние наднациональных организаций на регулирование международных, и в частности, межгосударственных отношений. Активизация внешнеполитической деятельности Украины предусматривает ее участие в таких межгосударственных объединениях. Доказано, что институциональная строение мировой фринансовой системы в условиях кризиса была вынуждена меняться. Изменения, происходящие носят не только институциональный характер, но и функциональный и правовой - изменяются функции международных фринансовых организаций, принимаются и утверждаются новые нормативы. Обосновано, что суть кредитной и инвестиционной деятельности международных фринансовых организации заключается в содействии развитию предпринимательской деятельности стран - заемщиц, привлечение средств для фринансирования дефицита государственного бюджета и платежного баланса, проведения структурных перестроек в экономике, реализации отдельных целевых социально - экономических программ и обеспечения других направлений развития. Ключевые слова: кредит, кредитование, кредитная политика, инвестиции, фринансовые организации.

The article examines the features of credit and investment policy of international financial organizations. International financial organizations carry out lending and investment activities to promote business development of borrowing countries, raise funds to finance the state budget deficit and balance of payments, structural adjustment in 
the economy, the implementation of certain targeted socio - economic programs and other areas of development. It is determined that in the current state of intensification of the processes of integration and globalization of the life of the international community the influence of supranational organizations on the regulation of international, and in particular, interstate relations is gradually growing. Analysis of scientific works of domestic and foreign scholars in the field of international monetary and financial cooperation emphasizes the importance of improving its institutional framework and mechanisms of cooperation of international financial organizations with member countries, especially in times of crisis. The purpose of the article is to determine the main features of credit and investment policy of international financial organizations. The future stable development of effective cooperation of Ukraine with international financial institutions is impossible without revision of the modern concept of bilateral relations and complex improvement of elements of the mechanism of monetary and financial cooperation. Intensification of Ukraine's foreign policy involves its participation in such intergovernmental associations. It is studied that the institutional structure of the world financial system in the crisis was forced to change. The changes that are taking place are not only institutional in nature, but also functional and legal - the functions of international financial organizations are changing, new standards are being adopted and approved. It is substantiated that the essence of credit and investment activity of international financial organizations is to promote business development of borrowing countries, raising funds to finance the state budget deficit and balance of payments, structural adjustment in the economy, implementation of certain targeted socio - economic programs and other areas of development. Key words: credit, crediting, credit policy, investments, financial organizations.

Постановка проблеми. В сучасному стані активізації процесів інтеграції та глобалізації життя міжнародного співтовариства поступово зростає вплив наднаціональних організацій на регулювання міжнародних, і зокрема, міждержавних відносин. Активізація зовнішньополітичної діяльності України передбачає її участь в таких міждержавних об'єднаннях.

В світлі подій, які на сучасному етапі відбуваються у відносинах між Україною та міжнародними фрінансовими організаціями, зокрема, такими як Міжнародний валютний фонд, Група Світового банку та регіональні фрінансові організації, постає питання необхідності перегляду механізму співробітництва як зі сторони України, так і зі сторони зовнішніх кредиторів. Недоліки у співробітництві, які останнім часом все частіше проявляються, в тому числі і з нашою державою, говорять про недосконалість функціонального чи організаційного механізму, який покладено в основу двосторонньої співпраці міжнародних фінансових інституцій з країнами - членами.

Значні проблеми все частіше проявляються у співробітництві з міжнародними фрінансовими організаціями. Недоліки побудованого механізму співробітництва лежать, перш за все, у підсистемах квотування, кредитування та правовій системі їхньої діяльності. Дослідження сучасного стану функціонування цих інституції дозволяє зробити об'єктивні висновки та розробити рекомендації, направлені на мінімізацію чи повну ліквідацію виявлених проблем.

Аналіз останніх досліджень і публікацій. Аналіз наукових праць вітчизняних та зарубіжних науковців в галузі міжнародного валютно - фрінансового співробітництва підкреслює важливість удосконалення його інституційної основи та механізмів співпраці міжнародних фрінансових організацій з країнами - членами, особливо в умовах кризи.

Питанням рефрормування міжнародного валют- но - фрінансового співробітництва, зокрема його інституціональної основи, досліджували вчені О. Примостка [11], Б. Самородов [12], Н. Холявко [15], С. Шкарлет [13] та інші, котрі, зокрема, з'ясовували правову та інституціональну природу сучасної міжнародної фінансової архітектури, проводили аналіз недоліків функціонування даних інституцій та займалися аспектами удосконалення міжнародних механізмів співробітництва. Питаннями пошуку шляхів до підвищення ефективності співробітництва України з МФО та удосконаленням механізму такого співробітництва займалися такі учені як В. Вовк [14], М. Дубина [1; 2], А.Жаворонок [3; 4], С. Кхалатур [6], В. Коваленко [7], Р. Лавров [8], В. Маргасова [9], О. Мінц [10] та інші. Вони займалися пошуком механізмів підвищення ефрективності співробітництва України з МФО, досліджували питання членства нашої держави у МФО.

Виділення невирішених раніше частин загальної проблеми, котрим присвячується означена стаття. Аналіз співробітництва нашої держави з міжнародними фрінансовими організаціями дає можливість прогнозувати сценарії розвитку майбутніх відносин та розробити рекомендації щодо вирішення ключових та актуальних проблем на поточному етапі співробітництва - отримання наступних сум кредитів та виконання Україною вимог, поставлених перед нею міжнародними фрінансовими організаціями. Отже, майбутній стабільний розвиток ефективної співпраці України з міжнародними фрінансовими інституціями неможливий без перегляду сучасної концепції двосторонніх відносин та комплексного удосконалення елементів механізму валютно - фінансового співробітництва.

Формулювання цілей статті (постановка завдання). Метою даної роботи $є$ визначення основних особливостей кредитної та інвестиційної політики міжнародних фінансових організацій.

Виклад основного матеріалу дослідження. 
Міжнародні фрінансові організації здійснюють кредитну та інвестиційну діяльність з метою сприяння розвитку підприємницької діяльності країн - позичальниць, залучення коштів для фрінансування дефріциту державного бюджету та платіжного балансу, проведення структурних перебудов в економіці, реалізації окремих цільових соціально - економічних програм та забезпечення інших напрямів розвитку.

З економічно точки зору, головний сенс наданих позик полягає в тому, що ці кредитні ресурси надаються під досить жорсткі умови, пов'язані з виконанням країною економічних програм, розроблених міжнародними фрінансовими організаціями.

Для того щоб зрозуміти ефрективність зовнішньої допомоги з боку міжнародних фрінансових організацій та її вплив на стан забезпечення економічної безпеки країн - членів, необхідно досліджувати особливості кредитної та інвестиційної політики МФО, на яких виділяються ці кредити.

Міжнародний валютний фронд (МВФ) надає допомогу для цілей стабілізації грошово - кредитної системи та поповнення валютних резервів. Один з найважливіших обов'язків МВФ полягає в наданні кредитів державам - членам, що стикаються з фактичними або потенційними труднощами в сфрері платіжного балансу. Ця фрінансова допомога необхідна країнам, які прагнуть поповнити свої міжнародні резерви, стабілізувати свої валюти, продовжувати оплачувати імпорт і відновити умови для активного економічного зростання одночасно з вживанням заходів по виправленню первинних проблем. На відміну від банків розвитку МВФ не надає кредити на конкретні проекти.

Основна діяльність МВФ - макроекономічна політика і політика відносно фрінансового сектора. При здійсненні нагляду за економічною політикою держав - членів МВФ в основному розглядає результати економіки в цілому за макроекономічними показниками. До них відносяться: загальний обсяг витрат; випуск продукції; зайнятість; інфрляція; платіжний баланс.

Держава - член може звернутися за фрінансовою допомогою МВФ, якщо у неї є потреба (фактична або потенційна) у фрінансуванні платіжного балансу, тобто вона не може знайти достатнього фрінансування на доступних умовах для покриття чистих міжнародних платежів при збереженні достатніх резервів на майбутнє. Кредит від МВФ забезпечує резервні можливості, що полегшують проведення заходів стабілізації і реформи, які країна повинна здійснити для виправлення проблеми платіжного балансу і відновлення умов для активного економічного зростання.

Процес кредитування МВФ полягає в наступному. Після отримання прохання держави - члена, зазвичай, МВФ надає кредит в рамках «домовле- ності», яка у певних випадках може передбачати конкретні політичні заходи і дії, які країна погоджується здійснити для вирішення своєї проблеми з платіжним балансом. Економічна програма, що $€$ основою домовленості, розробляється країною на основі консультацій з МВФ і представляється Виконавчій раді Фонду в «Листі про наміри». Як тільки Рада затверджує домовленість, кредит зазвичай виділяється частинами поетапно по мірі реалізації програми. Деякі домовленості забезпечують країнам одноразовий негайний доступ до фрінансових ресурсів МВФ [11].

3 часом МВФ розробив різні кредитні інструменти або «механізми», які були адаптовані для подолання конкретних ситуацій різних держав членів.

Країни з низькими доходами можуть запозичувати засоби по пільгових процентних ставках через розширений кредитний механізм (далі-ЕСФ), кредитний механізм «стенд - бай» (далі-ССФ) і механізм прискореного кредитування (далі РСФ).

Фінансування в рамках ЕСФ в даний час здійснюється під нульову процентну ставку, з пільговим періодом в $51 / 2$ роки і повним терміном погашення в 10 років.

Кредитний механізм «стенд - бай» (ССФ) використовується для надання фрінансової підтримки країнам з низькими доходами, які зазнають короткострокові труднощі з врегулюванням платіжного балансу. Фінансування в рамках ССФ в даний час здійснюється під нульову процентну ставку, з пільговим періодом в 4 роки і повним терміном погашення за 8 років.

Механізм прискореного кредитування (РСФ) забезпечує швидку фрінансову допомогу при обмеженому пред'явленні умов і призначений для країн з низькими доходами, що зіткнулися з терміновими потребами для врегулювання платіжного балансу. Фінансування в рамках РСФ в даний час здійснюється під нульову процентну ставку, з пільговим періодом в 51/2 роки і повним терміном погашення за 10 років.

Непільгові кредити надаються в основному через домовленості про кредит «стенд - бай» (далі - СБА), гнучку кредитну лінію (далі - ГКЛ), превентивну кредитну лінію (далі - ПКЛ) і механізм розширеного кредитування (який використовується в основному для більш довгострокових потреб). МВФ також надає екстрену допомогу всім своїм державам - членам, що потребують сприяння для відновлення після стихійних лих і конфрліктів. В разі всіх непільгових механізмів діє процентна ставка МВФ, пов'язана з ринковою. Вона іменується «ставкою зборів», і по крупних позиках стягується додатковий збір.

Основна частина допомоги Фонду країнам з низькими доходами надається через СБА. СБА 
призначені для допомоги країнам в подоланні короткострокових проблем з платіжним балансом. Цілі програм передбачають вирішення цих проблем, а виплати засобів Фондом обумовлені досягненням цих цілей. Термін дії СБА складає зазвичай 12-24 місяців, кредит погашається протягом 5 років з моменту фактичного надання. Кредити СБА можуть надаватися в порядку обережності (коли країни вважають за краще не використовувати затверджені кредити, але зберігають можливість зробити це при погіршенні ситуації) як із звичайними лімітами доступу, так і у випадках виняткового доступу. СБА передбачає гнучкість відносно етапів, у відповідних випадках з концентрацією засобів, що надаються, на початковому етапі.

Гнучка кредитна лінія (ГКЛ) призначена для країн з дуже хорошими основними економічними показниками, обґрунтованою економічною політикою і успішним досвідом проведення політики, і особливо корисна для запобігання кризі, хоча вона також може використовуватися для вживання антикризових заходів. Термін дії ГКЛ складає 1-2 роки, а період погашення є таким же, як для СБА. Доступ визначається з врахуванням конкретної ситуації, на нього не поширюються звичайні ліміти доступу, засоби можуть надаватися відразу одним платежем, а не поетапно. Фактичне надання засобів в рамках ГКЛ не обумовлене реалізацією конкретних домовленостей відносно економічної політики, як в разі СБА.

Превентивна кредитна лінія (ПКЛ) може використовуватися лише в цілях запобігання кризам країнами з надійними основними економічними показниками, обґрунтованою економічною політикою і успішним досвідом проведення такої політики. Тривалість ПКЛ може складати від 1-2 років. Доступ може надаватися з концентрацією на початковому етапі в розмірі до 500\% квоти і відкриватися після затвердження домовленості, і в цілому досягати 1000\% квоти після 12 місяців за умови успішного зниження чинників вразливості.

Механізм розширеного кредитування створений для подолання більш довгострокових проблем, пов'язаних з платіжним балансом. Тому термін домовленостей в рамках ЕФФ- переважно 3 роки. Термін погашення: 41/2-10 років з дня фрактичного надання засобів.

Екстрена допомога - МВФ надає екстрену допомогу країнам, які пережили стихійне лихо або долають наслідки конфллікту. По екстрених кредитах стягується базова ставка зборів. Кредити повинні погашатися протягом 31/2-5 років.

Отже, МВФ здійснює кредитування за різними цілями, у різних формах та на різних умовах. Воно включає кредитування для потреб вирівнювання платіжного балансу, компенсаційне фінансування та допомогу найбіднішим країнам.
Офріційні цілі усіх членів Групи Світового банку - зменшення бідності і підвищення життєвих стандартів країн - членів шляхом сприяння економічному розвитку останніх і залучення ресурсів з розвинених країн до країн, що розвиваються. Кожна з установ Групи Світового банку має свої функції і відіграє самостійну, якісно відмінну роль.

Описуючи кредитну та інвестиційну діяльність Групи Світового банку, в першу чергу слід звернути увагу на Міжнародний банк реконструкції та розвитку (МБРР), який спрямовує допомогу на підтримку бюджету та фінансування різних секторальних інвестиційних проектів. Однак варто зазначити, що надані цією міжнародною організацією кошти не йдуть безпосередньо на розвиток виробництва, а використовуються насамперед для:

- цілей приватизації;

- лібералізації торгівлі;

- надання консультативних послуг;

- технічної допомоги;

- розвитку ринку цінних паперів.

Кредитна політика МБРР відповідає інтересам приватного капіталу, функціонуючого в країнах. Це проявляється в самій процедурі розгляду заявок країн - членів на банківські кредити. При вирішенні питання про надання коштів МБРР вимагає повну інформацію про економічний та фрінансовий стан країн, куди потім він направляє свої економічні місії.

Терміни, обсяги і ставки кредитів МБРР визначаються особливостями проекту, що кредитується. Як і МВФ, МБРР звичайно обумовлює надання кредитів певними умовами. Всі позики банку повинні гарантуватися урядами країн - членів. Позики виділяються під процентну ставку, яка змінюється кожні 6 місяців. Позики надаються, як правило, на 15-20 років з відстрочкою платежів по основній сумі позики від 3 до 5 років. Ставка кредиту в середньому перевищує на 0,5\% ставку по позиковим коштам банку. Оскільки МБРР залучає позики з розрахунку 7\% щорічних, то кредитна ставка складає в середньому - 7,5\% [9].

Погашення кредиту і нарахованих по ньому відсотків здійснюється позичальником банку - кредитору відповідно до умов кредитного договору з розрахункового рахунку. Виплата нарахованих відсотків по кредиту здійснюється позичальником щомісячно, починаючи з моменту надання кредиту. Відсотки за користування кредитом нараховуються з моменту першого платежу по графіку кредитування. Повернення основної суми кредиту проводиться по частинах і може бути відстрочений до 2 років за наявності відповідного обґрунтування.

Позичальник повинен мати заплановане накопичення коштів або збільшення акціонерного капіталу, достатнє для здійснення необхідних витрат 
за проектом. Для мікропідприємств, які відповідають всім вищезгаданим вимогам і загальна сума активів не перевищує 100000 дол. США - 100\% вартості проекту може фінансуватися за рахунок коштів кредиту.

Кредит надається в доларах США тільки для фінансування витрат на товари та послуги зарубіжного або вітчизняного походження виключно для: довгострокового фрінансування засобів виробництва (до 5 років); фрінансування постійного оборотного капіталу (до 1 року); короткострокового фрінансування витрат на виробництво; фрінансування лізингу.

Кредит МБРР не надається для: рефрінансування існуючих зобов'язань позичальника по відношенню до уповноваженого банку; фрінансування внесків до статутних фондів; фінансування проектів, пов'язаних з гральним бізнесом, виробництвом та реалізацією зброї, тютюнових виробів, міцних спиртних напоїв, ювелірних виробів; будівництва житлових споруд; фрінансування витрат, які створюють загрозу для оточуючих, тобто виробництво, використання і імпорт яких заборонене згідно законів України або міжнародних угод, до яких приєдналася Україна [6].

Необхідно підкреслити, що Банк покриває своїми кредитами лише 30\% вартості об'єкта, причому найбільша частина кредитів направляється в галузі інфрраструктури: енергетику, транспорт, зв'язок.

Доповнює діяльність МБРР в напрямі довгострокового фрінансування найбідніших країн світу Міжнародна асоціація розвитку. Свою діяльність MAР спрямовує на допомогу країнам, що розвиваються, через заохочення розвитку приватного сектора, мобілізації внутрішніх і зовнішніх джерел капіталу.

MAР надає фрінансову допомогу країнам, що розвиваються у вигляді кредитування конкретних проектів. Кредити мають 10 - ти річний період відстрочки і підлягають сплаті протягом 30-40 - річного періоду. Також МАР надає допомогу країнам які не відповідають критеріям отримання позик, але вони не мають достатній рівень кредитоспроможності для отримання кредитів від МБРР. На даний момент критеріям для отримання позик від МАР відповідають 80 країн, 39 з яких знаходяться в Африці.

Кредити спрямовуються в основному в розвиток інфраструктури і в сільське господарство. Іноді МАР і МБРР спільно кредитують один і той же об'єкт, якщо на нього необхідні великі кошти.

Інвестори, що вступають в партнерство з МФК, мають можливість використовувати досвід Корпорації в галузі управління ризиком в країнах з ринком.

МФК здійснює свою діяльність на комерційній основі. Вона інвестує кошти виключно в комерційні проекти і стягує ринкові процентні ставки за свої продукти і послуги.

Надані МФК позики спрямовуються як на фрінансування нових підприємств, так і на розвиток діючих проектів в країнах, що розвиваються. Корпорація також надає позики банкам - посередникам, лізинговим компаніям та іншим фрінансовим установам за рахунок кредитних ліній, які використовуються для подальшого кредитування. Кредитні лінії нерідко носять цільовий характер і призначені для малих і середніх підприємств або для конкретних галузей.

МФК надає позики з фіксованою і змінною ставками за рахунок власних коштів для фінансування проектів у приватному секторі країн, що розвиваються. Як правило, на момент оформлення терміни погашення позик становлять 7-12 років. Пільгові періоди і графріки погашення визначаються на індивідуальній основі у відповідності з поточними потребами позичальника в готівки. Якщо цього вимагає проект, то МФК надає позики з більш тривалими термінами погашення та пільговим періодом. У деяких випадках позики надаються на термін до 20 років.

Як правило, розмір позик від МФК становить від $1 \mathrm{млн.} \mathrm{до} 100$ млн. дол. США. Корпорація готова надавати позики, які погашаються виключно за рахунок потоку готівки, забезпечуваного проектом, без участі або з мінімальною участю спонсорів.

Взаємодоповнюючу діяльність з МФК по направленню на сприяння економічному зростанню і залученню приватного капіталу в економіку найбідніших країн світу, здійснює Багатостороннє Агентство Гарантій Інвестицій (БАГІ).

БАГІ доповнює діяльність інших міжнародних страхувальників і пропонує чотири основних типи гарантій:

Неконвертованість валюти - це захист від втрат, які виникли у зв'язку з неможливістю конвертувати місцеву валюту в іноземну для ії переказу за межі країни перебування.

Експропріація - захист від втрат, які викликані діями уряду країни перебування у зв'язку з обмеженням або ліквідацією права власності чи контролю над нею, а також права на застраховані інвестиції.

Війна і громадянські заворушення - це захист від збитків, викликаних військовими діями або громадянськими заворушеннями, які призвели до руйнування чи нанесення шкоди матеріальним активам підприємства або до створення перешкод для його діяльності.

Порушення умов контрактів - це відмова від зобов'язань за контрактом з отримувачем гарантій або його порушення з боку уряду країни перебування, коли отримувач гарантій не має змоги звернутися до суду чи арбітражного суду для розгляду позову про відмову від контракту або порушення його умов; рішення суду не приймається в розумні 
терміни; таке рішення не може бути виконано.

БАГІ не надає кредити і не є самостійним інвестором. Гарантії не виділяються для інвестицій у виробництво тютюну і алкоголю, в організацію азартних ігор. Максимальний розмір гарантій складає в даний час 110 млн. дол. США на один інвестиційний проект і 440 млн. дол. США на одну країну.

Серед регіональних фрінансових організацій активно кредитну та інвестиційну діяльність проводять ЄБРР та ЄІБ.

При проведенні своїх операцій ЄБРР слідує найвищим стандартам корпоративного управління та сталого розвитку, будучи публічною організацією, ЄБРР прихильний строгим принципам оприлюднення інформації.

ЄБРР застосовує широкий набір інструментів фрінансування, виходячи з особливостей конкретних проектів. Головними серед цих інструментів $€$ кредити, пайова участь в капіталі компаній і надання. По всім своїм операціям ЄБРР слідує раціональним принципам ведення банківської діяльності. Про міцність капітальних позицій ЄБРР свідчить те, що йому присвоєно рейтинг AАА зі стабільним прогнозом, який був підтверджений всіма трьома основними рейтинговими агентствами.

Кредити ЄБРР мають наступні характеристики:

1) мінімальна сума становить 5 млн. євро, хоча для деяких країн може встановлюватися в меншому розмірі;

2) фріксована або плаваюча процентна ставка;

3) старший, субординований, проміжний або конвертований кредит;

4) номінований в основних іноземних або деяких національних валютах;

5) термін погашення від коротких до тривалих від 1 року до 15 років;

6) при необхідності для окремих проектів надаються пільгові періоди.

Як правило, кредити погашаються рівними і виробленими раз на півріччя платежами. У виняткових випадках можуть встановлюватися більш тривалі терміни погашення 3 нерівномірними платежами, наприклад, до 15 років по типом іпотеки для великомасштабних інфраструктурних проектів.

ЄБРР також сприяє таким фрінансовим посередникам, як національні комерційні банки, банки мікро - фрінансування, фронди прямих інвестицій та лізингові компанії.

Для отримання фрінансування від ЄБРР проект повинен відповідати наступними критеріями: здійснюватися в країні операцій ЄБРР; мати хороші економічні перспективи; припускати внесення його спонсором великого внеску до статутного капіталу в грошовій або натуральній фрормі; служити інтересам вітчизняної економіки та сприяти розвитку приватного сектора; відповідати банківським та екологічним стандартам.

ЄБРР розробляє кожен проект з урахуванням потреб клієнта та специфіки країни, регіону або галузі. Як правило, ЄБРР фрінансує до 35\% загальної вартості проекту, якщо він реалізується «з нуля» або $35 \%$ у разі довгострокової капіталізації проектної компанії. ЄБРР вимагає від спонсорів внесення великих внесків до статутного капіталу в обсязі, що дорівнює інвестиціям ЄБРР або вище.

ЄБРР не фрінансує: оборонну промисловість; виробництво тютюнових виробів; виробництво деяких алкогольних напоїв; виробництво речовин, заборонених міжнародно - правовими актами; гральні заклади, що мають самостійний баланс.

Європейський інвестиційний банк (ЄIB) традиційно відповідав за інфраструктурні проекти в ЄС - транспорт, енергетику, промисловість а тепер він поширює свої інтереси на сферу енергетичної безпеки і стимулювання розвитку приватного сектору.

ЄIB має декілька фрінансових механізмів:

Індивідуальні позики - це позики, які надаються для конкретних проектів як у державному, так і приватному секторі, включаючи банківську справy.

Глобальні позики - це кредитні лінії, котрі надаються посередникам (банкам, лізинговим компаніям або фінансовим установам), які у свою чергу дають позики органам місцевої влади або малим та середнім підприємствам для нових інвестиційних проектів обсягом до 25 млн. євро. Структуровані кредитні лінії забезпечують крупні позики та гарантії на підтримку проектів з високим ступенем ризику, зокрема крупномасштабні інфраструктурні програми, які ЄІВ починає дедалі більше фінансувати.

Висновки з цього дослідження і перспективи подальших розвідок у даному напрямку. Досліджено, що інституційна будова світової фрінансової системи в умовах кризи була вимушена змінюватися. Зміни, що відбуваються носять не лише інституційний характер, але і функціональний та правовий - змінюються функції міжнародних фрінансових організацій, приймаються та затверджуються нові нормативи.

Отже, суть кредитної та інвестиційної діяльності міжнародних фрінансових організації полягає в сприянні розвитку підприємницької діяльності країн - позичальниць, залучення коштів для фрінансування десріциту державного бюджету та платіжного балансу, проведення структурних перебудов в економіці, реалізації окремих цільових соціально - економічних програм та забезпечення інших напрямів розвитку. 


\section{БІБЛІОГРАФІЧНИЙ СПИСОК:}

1. Дубина М. В. Економічна суть та види фрінансових послуг. Світ фрінансів. 2016. №3(48). С. 124-135.

2. Dubyna M., Zhavoronok A., Kudlaieva N. \& Lopashchuk I. Transformation of Household Credit Behavior in the Conditions of Digitalization of the Financial Services Market. Journal of Optimization in Industrial Engineering. 2021. 14(1). P. 97-102.

3. Жаворонок А. Міжнародний досвід функціонування ринку кредитних послуг. Економічний дискурс. 2020. 1. C. $68-77$.

4. Жаворонок А.В. Проблеми вдосконалення механізму банківського кредитування як засобу стимулювання розвитку ринку кредитних послуг в Україні. Вісник економічної науки України. 2020. № 1 (38). С. $196-201$.

5. Жаворонок А. Тенденції розвитку ринку кредитних послуг в Україні. Галицький економічний вісник. 2020. 63 (2). C. 145-155.

6. Khalatur S., Zhylenko K., Masiuk Y., Velychko L. \& Kravchenko M. (2018). Assessment of bank lending diversification in Ukraine. Banks and Bank Systems. 2018. 13(3), 141-150.

7. Kovalenko V. \& Kerimov A. Internarial standards of financial support stability of the banking system. Economic and Social Development. 37 th International Scientific Conference on Economic and Social Development - "Socio Economic Problems of Sustainable Development". Book of Proceedings. 2019. P. 938-947.

8. Lavrov R., Beschastnyi V., Nikolenko L., Yousuf A., Kozlovskyi S., Sadchykova I. Special aspects of the banking institutions rating: a case for Ukraine. Banks and Bank Systems. 2019. 14(3). P. 48-63.

9. Margasova V., Muravskyi O., Vodolazska O., Nakonechna H., Fedyshyn M. \& Dovgan L. Commercial Banks as a Key Element in Regulating Cash Flows in the Business Environment. International Journal of Recent Technology and Engineering. 2019. 8 (4). C. 4537-4543.

10. Mints O., MarhasovaV., Hlukha H., Kurok R., \& Kolodizieva T. Analysis of the stability factors of Ukrainian banks during the 2014-2017 systemic crisis using the Kohonen self-organizing neural networks. Banks and Bank Systems. 2019. 14(3). P. 86-98.

11. Prymostka O. \& Prymostka L. Ukrainian banking system efficiency after double reducing of the number of bank institutions. Banks and Bank Systems. 2018. 13(4). P. 51-60.

12. Samorodov B.V., Azarenkova G.M., Golovko O.G., Miroshnik O.Yu. \& Babenko M.V. Credit risk management in the bank's financial stability system. Financial and credit activity: problems of theory and practice. 2019. 4 (31). P. 301-310.

13. Shkarlet S., Dubyna M., Zhuk O. Determinants of the financial services market functioning in the era of the informational economy development. Baltic Journal of Economic Studies. 4(3). 2018. P. 349-357.

14. Shkarlet S., Dubyna M., Vovk V., \& Noga M. (2019). Financial service markets of Eastern Europe: a compositional model. Economic Annals-XXI, 176 (3-4), 26-37.

15. Zhavoronok A., Kholiavko N. Banking system of Ukraine: trends and prospects of development. Modern Science - Moderní věda. 2020. No 10. P. 129-142.

\section{REFERENCES:}

1. Dubyna, M. V. (2016) Ekonomichna sutj ta vydy finansovykh poslugh [Economic nature and types of financial services]. Svit finansiv - The world of finance. 3(48). 124-135. [in Ukrainian].

2. Dubyna, M., Zhavoronok, A., Kudlaieva, N., \& Lopashchuk, I. (2021) Transformation of Household Credit Behavior in the Conditions of Digitalization of the Financial Services Market. Journal of Optimization in Industrial Engineering, 14(1), 97-102.

3. Zhavoronok, A. (2020) Mizhnarodnyi dosvid funktsionuvannia rynku kredytnykh posluh [International experience in the operation of the credit services market]. Ekonomichnyi dyskurs - Economic discourse, 1, 68-77. [in Ukrainian].

4. Zhavoronok, A. V. (2020) Problemy vdoskonalennia mekhanizmu bankivskoho kredytuvannia yak zasobu stymuliuvannia rozvytku rynku kredytnykh posluh $v$ Ukraini [Problems of improving the mechanism of bank lending as a means of stimulating the development of the credit services market in Ukraine]. Visnyk ekonomichnoi nauky Ukrainy - Bulletin of Economic Science of Ukraine, 1(38), 196-201. [in Ukrainian].

5. Zhavoronok, A. (2020) Tendentsii rozvytku rynku kredytnykh posluh v Ukraini [Trends in the development of the credit services market in Ukraine]. Halytskyi ekonomichnyi visnyk - Galician Economic Bulletin, 63(2), 145-155. [in Ukrainian].

6. Khalatur, S., Zhylenko, K., Masiuk, Y., Velychko, L. \& Kravchenko, M. (2018) Assessment of bank lending diversification in Ukraine. Banks and Bank Systems, 13(3), 141-150.

7. Kovalenko, V., \& Kerimov, A. (2019) Internarial standards of financial support stability of the banking system. Economic and Social Development. 37 th International Scientific Conference on Economic and Social Development - "Socio Economic Problems of Sustainable Development". Book of Proceedings, 938-947.

8. Lavrov, R., Beschastnyi, V., Nikolenko, L., Yousuf, A., Kozlovskyi, S., \& Sadchykova, I. (2019) Special aspects of the banking institutions rating: a case for Ukraine. Banks and Bank Systems, 14(3), 48-63.

9. Margasova, V., Muravskyi, O., Vodolazska, O., Nakonechna, H., Fedyshyn, M., \& Dovgan, L. (2019) Commercial Banks as a Key Element in Regulating Cash Flows in the Business Environment. International Journal of Recent Technology and Engineering, 8 (4), 4537-4543. 
10. Mints, O., Marhasova, V., Hlukha, H., Kurok, R., \& Kolodizieva, T. (2019) Analysis of the stability factors of Ukrainian banks during the 2014-2017 systemic crisis using the Kohonen self-organizing neural networks. Banks and Bank Systems, 14(3), 86-98.

11. Prymostka, O. \& Prymostka, L. (2018) Ukrainian banking system efficiency after double reducing of the number of bank institutions. Banks and Bank Systems, 13(4), 51-60.

12. Samorodov, B. V., Azarenkova, G. M., Golovko, O. G., Miroshnik, O. Yu., \& Babenko, M. V. (2019) Credit risk management in the bank's financial stability system. Financial and credit activity: problems of theory and practice. 4(31). P. 301-310.

13. Shkarlet, S., Dubyna, M., \& Zhuk, O. (2018) Determinants of the financial services market functioning in the era of the informational economy development. Baltic Journal of Economic Studies. 4(3). 349-357.

14. Shkarlet, S., Dubyna, M., Vovk, V., \& Noga, M. (2019) Financial service markets of Eastern Europe: a compositional model. Economic Annals-XXI, 176 (3-4), 26-37.

15. Zhavoronok, A., \& Kholiavko, N. (2020) Banking system of Ukraine: trends and prospects of development. Modern Science - Moderní věda, 10, 129-142. 